\title{
The effect of the intensity and method of pruning on the growth and yield of the apple variety 'Idared' under conditions of ecological and integrated growing systems
}

\author{
Dremák, P., Gonda, I., Szabó, Z. \& Nyéki, J. \\ University of Debrecen Centre for Agricultural and Applied Economic Sciences \\ H-4032 Debrecen, Böszörményi út 138., Hungary
}

\begin{abstract}
Summary: On the Experimental Farm of the Debrecen University at Pallag, a factorial experiment has been started at springtime of 2008 on an orchard of 12 year old apple trees 'Idared' grafts on M 26 understocks. The first factor was the growing system (integrated versus ecological), the second was the intensity of pruning (strong versus moderate thinning of the crown), whereas the third was the method of pruning (shortening versus thinning of individual shoots). Measurements have been concentrated on shoot growth, flower initiation, fruit set and accumulated yield of two successive seasons. The following conclusions are made.

- In the ecological growing system, strong thinning proved to be beneficial for growth as well as for fruit bearing.

- Strong thinning combined with shortening of shoots diminished yield in the first year, whereas

moderate thinning combined with shortening of shoots caused favourable growth and fruit bearing.

- In the ecological growing system, the moderate shoot growth was associated with better flower initiation, which increases the chances of alternate yielding.

- According to our results, the flower initiation of the 'Idared' was stimulated univocally by the thinning of shoots regardless of the intensity of pruning.

The right choice of the intensity and method of pruning is a decisive moment of a successful yield in the ecological apple growing system
\end{abstract}

Key words: ecological, integrated growing system, pruning methods, alternate yielding

\section{Introduction}

The ecological growing system of apple produces inferior results as the admitted methods of nutrition and plant protection cannot provide for those conditions as usually secured by the integrated growing system (Gonda, 2005; Holb et al., 2005ab). The nutrients delivered by the soil and the photosynthetic activity of the canopy are temporarily or permanently limited, therefore the growth and performance of apple trees in the ecological growing system diminishes remarkably. Among the phytotechnical elements of the growing system, pruning is the most decisive regarding its influence on shoot growth as well as on the formation of fruiting bodies, flowers and fruits (Gonda, 2005).

The fundamental objective of our experiment was definitely to strengthen the weak conditions securing reduced potential of the plant by relatively intense pruning, which may stimulate lively growing within certain limits. Pruning is able to overcome the apparent lack of vitality and restore optimal conditions (Zatykó, 1979). According to Zatykó, optimal conditions depend on the healthy balance between vegetative activity and provision of assimilates.

Our experimental object, 'Idared', is known to need, now and then, strong pruning in the traditional as well as integrated practice of growers. At the same time, more or less shortening of the shoots is also recommended. Interventions of this type are necessary to stimulate shoot growth, which is essential for building up conditions for the development of fruits in the current and the next year.

Based on those considerations, the pruning experiment has been planned and started in the spring of 2008 .

\section{The locality, material and method of the experiment}

At the Experimental Station, Pallag, of the Debrecen University, the sandy, brown forest soil is typical for the southern part of the Nyirség region. It is of low humus content and poor of macronutrients.

Pruning has been performed in late February and early March when the trees were still dormant. Each treatment comprised 7 trees, which are distributed randomly in the whole plantation.

\section{The treatmnets:}

a., Strong thinning: Two-year-old wood was reduced to one year old horizontal shoots, meanwhile, perpendicular or nearly perpendicular ones are eliminated at their base. 
This pruning may reduced by $30 \%$ the volume of the canopy as estimated.

c., Moderate thinning: Only the most necessary shoots are cut off for thinning. The volume of the crown is reduced by circa $15 \%$ as estimated.

d., Moderate thinning + shoots are left relatively long: like c., + shoots of $40 \mathrm{~cm}$ and longer than that are shortened by $1 / 3$-rd of their length.

During the performance, the ideas of Zahn (1986) are considered, i.e. the thickness relation of the main axis and branch..

The indices of growth, initiation of fruiting structures and yield are the following ones:

- Shoot growth $\mathrm{cm} /$ cross section area of the branch $\mathrm{cm}^{2}$

- Total length cm of 2-year-old shoots

- Development of fruiting structures / shoot length running meter

- Yield of fruits $\mathrm{kg} /$ tree and fruit / cross section area of the trunk $\mathrm{cm}^{2}$

- Fruit set as number of fruits / cross section area of the trunk $\mathrm{cm}^{2}$

- Number of inflorescences / cross section area of the trunk $\mathrm{cm}^{2}$

Results are processed by variance analysis according to the method of factorial experiments

\section{Results}

The first figure presents the effect of different pruning techniques on final fruit set.

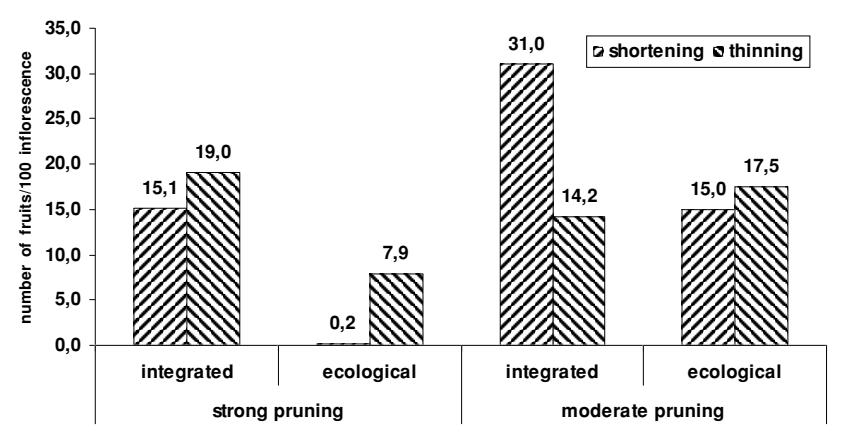

Figure 1. Effect of different pruning techniques on fruit set of 'Idared' apple trees grafted upon M 26 rootstock in the integrated as well as in ecological growing system (Debrecen-Pallag, 2008)

The final fruit set per one hundred inflorescences was influenced equally by the different pruning techniques but also by the growing systems. In integrated system, the strong thinning of the crown was less modified by the manner of pruning technique (shortening versus thinning of shoots), whereas in the moderate thinning of the crown, the pruning technique was highly decisive regarding fruit sets. It is convincing that in moderately thinned crowns, the shortening of shoots set more fruits than where the shoots were only thinned. In the ecological growing system, however, strong pruning combined with shoot-shortening caused drastic drop of fruit sets, but also the strong thinning proved to be relatively deleterious.

The second figure shows the final fruit set data in integrated as well as in ecological growing systems regarding the average of pruning methods, i.e. independently from the pruning techniques

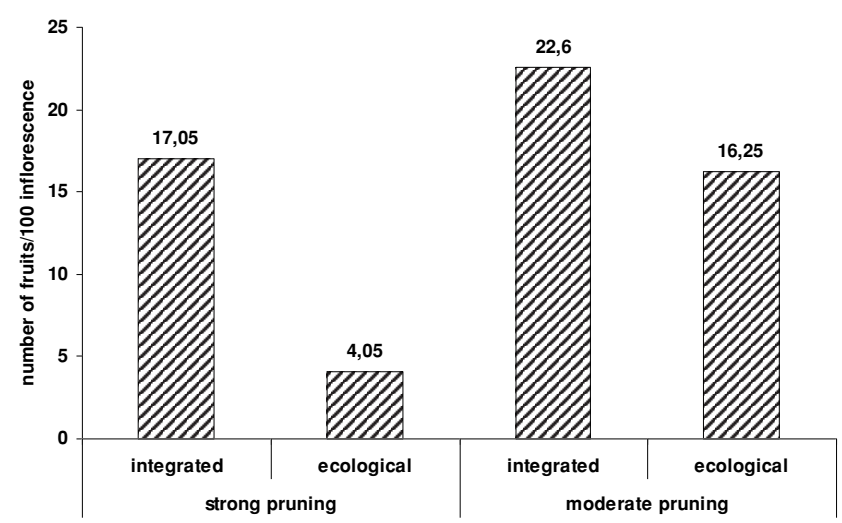

Figure 2. The effect of moderate pruning on fruit set on 'Idared' apple trees grafted on M 26 stock in integrated as well as in ecological growing systems, independently from the method of pruning techniques (Debrecen-Pallag, 2008)

The independence of final fruit set from the pruning method applied shows convincingly the advantages of the integrated growing system versus the ecological one, where the physiological conditions (low fruit setting potential) of plants were inferior. The strong thinning of crown diminished fruit set markedly in both growing systems but mainly in the ecological one. In fruit load of trees, the difference is more conspicuous if the number of fruits was related to the cross section area of the trunks, which is visible in Figure 3.

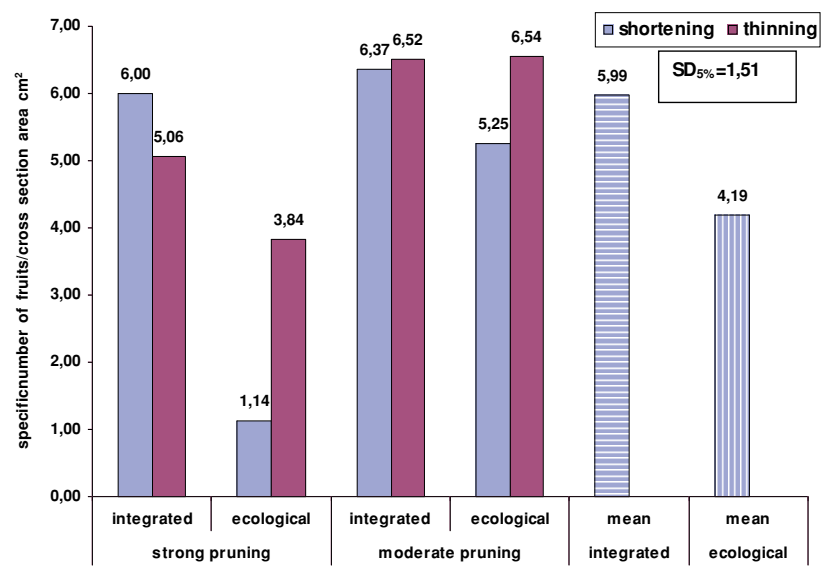

Figure 3. The effect of the intensity of pruning on the specific fruit load of 'Idared' apple trees grafted on M 26 rootstock in ecological as well as in integrated growing systems (Debrecen-Pallag, 2008)

As presented on the figure, the specific number of fruits is largely according to the figures of fruit set, however, the differences are decreasing with the relative saturation of fruit 
load. In ecological growing, strong thinning and the shortening of shoots lowers drastically the yield per tree like the rate of fruit set.

Among the two growing systems, the integrated trees produced yields superior by $30 \%$ than in the ecological growing system independently from the pruning method. Moderate thinning of crowns, with shortening of shoots diminished the specific fruit load (by about 20\%), but less effectively than related to strong thinning.

In figure 4, the joint effect of pruning and growing systems on the shoot growth is visible.

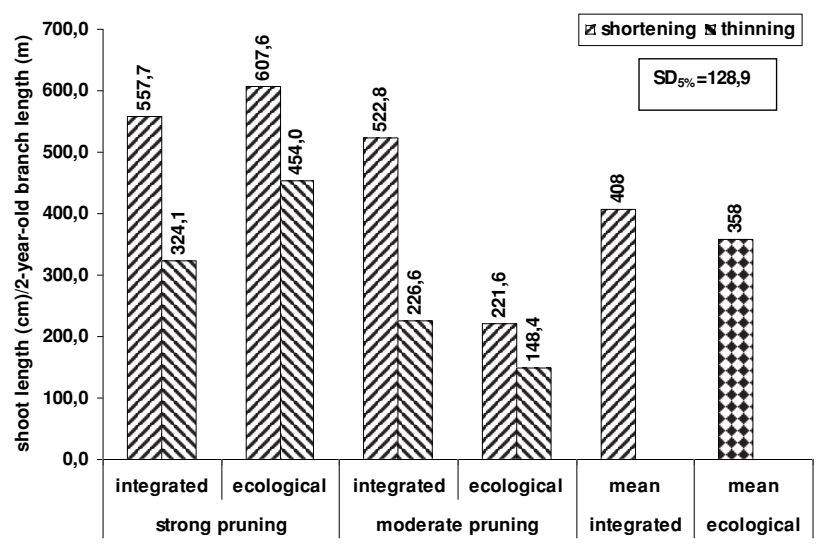

Figure 4. Effect of the intensity as well as of the method of pruning on 'Idared' apple trees grafted on M 26 rootstock affecting total shoot growth as well as specific shoot length in integrated and ecological growing systems. (Debrecen-Pallag, 2008)

We are stating that in almost all treatments, the shortening of shoots stimulated growth better than the thinning of shoots. Strong thinning of the crown coupled with shortening of shoots stimulated outstanding growth of shoots, which was due to extremely low fruit loads (see figure 3). In the integrated growing system, the shortening of shoots produced almost the same growth intensity, beside substantial fruit loads by tree, which proves the higher vitality and better conditions proper to that growing system. In the ecological system, the moderately thinned trees grew

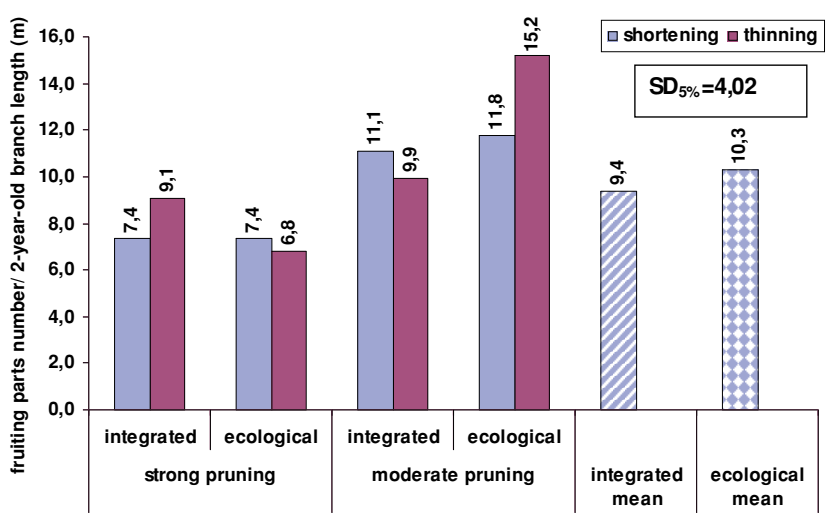

Figure 5. The effect of pruning methods on the specific quantity of fruiting structures developed during the season of pruning in 'Idared' apple trees grafted on M 26 root in ecological and integrated growing systems (Debrecen-Pallag 2008) rather moderately. Regardless of pruning methods, the integrated growing system produced more (by 15\%) shoot growth than the ecological system.

Figure 5 shows the number of fruiting structures developed during the season of pruning in trees of integrated as well as in ecological growing system.

The data suggest that the development of fruiting structure was more stimulated under the moderate pruning method than under strong pruning. Obviously, the vegetative activity was reduced to the shortened shoots. In the ecological growing system, about $10 \%$ more fruiting bodies appeared independently from pruning systems.

After pruning, in the next year, we checked the number of flowers on the experimental trees.

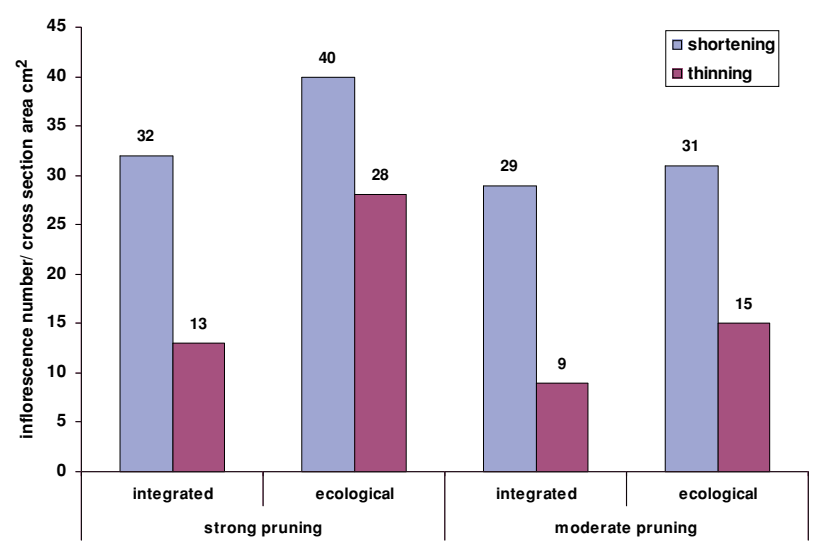

Figure 6. Effect of intensity and method of pruning on the blooming of the next year on 'Idared' apple trees grafted into M 26 roots in ecological as well as integrated growing system (Debrecen-Pallag 2009)

The figure proves the stimulating effect of all kind of shoot shortening on flower formation versus shoot thinning techniques. In the integrated system both, strong and moderate thinning of the crown, moreover, shortening of shoots produced nearly similar flowering intensity. On the other hand, in ecological growing system, the strong pruning (either thinning or shoot shortening) increased the flowering even more than moderate pruning. It is the unequivocal consequence of low fruit loads of the past years. The flower

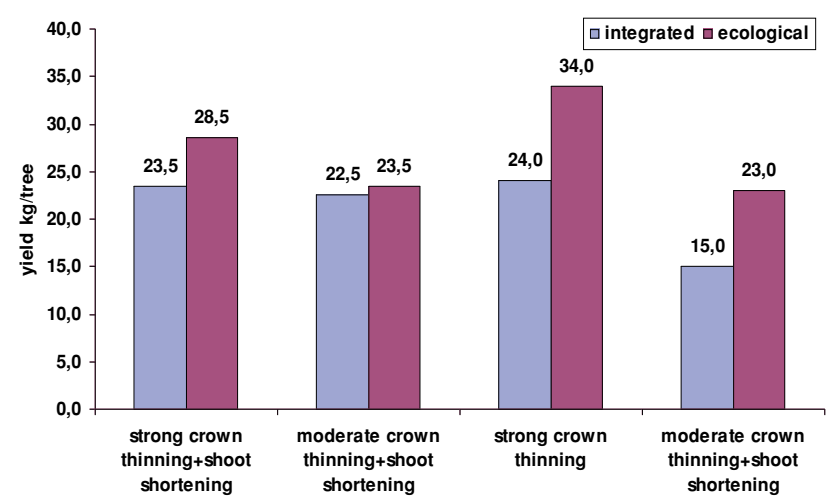

Figure 7. Consequence of the intensity and method of pruning on 'Idared' apple trees grafts of M 26 expressed in the fruit load of the next year (Debrecen-Pallag 2009) 
density of 2009 is a reflection of the past year. The flower densities observed in the rest of pruning treatments are also proving the effects of the fruit load of previous years. 2009.

Figure 7 informs us on the after effects of pruning in

Among the yields in the year 2009, those treatments are outstanding, which comprised strong thinning of the crowns and pruning of the shoots, in the ecological growing system. It was explained to be the consequence of the low yields of the past year. Highest yields are harvested on trees strongly pruned in the ecological growing system, which was also attributed to the relatively low yields of the previous year.

In the rest of treatments, yields are considered to be largely similar to those harvested in the previous season.

Accumulated yields of the two successive years (of pruning and the next year) are presented in figure 8.

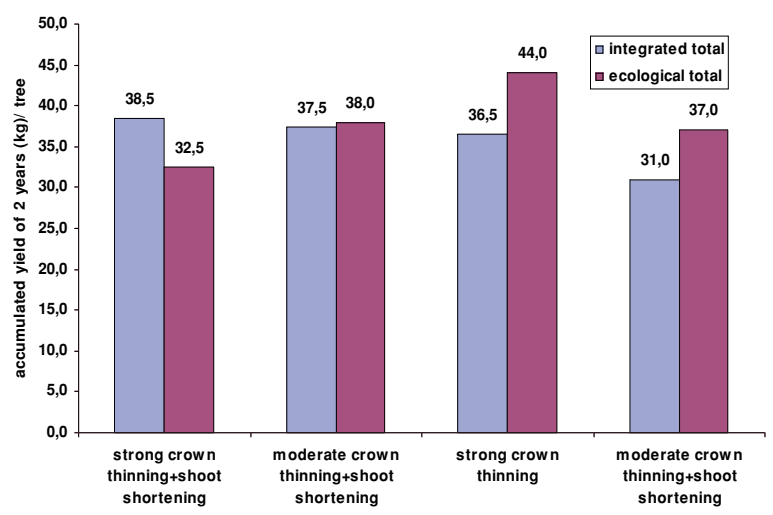

Figure 8. Consequence of the intensity and method of pruning on the accumulated yields of the to experimental trees (Debrecen-Pallag, 20082009)

The accumulated fruit yields of the experimental trees varied between 31 and $44 \mathrm{~kg} / \mathrm{tree}$, and are considered to be rather balanced. In the integrated growing system, highest yields are found on the treatments involving shortening of shoots $(37,5-38,5 \mathrm{~kg} /$ tree $)$, meanwhile treatments of moderately thinned shoots produced less yield (by 7 $\mathrm{kg} / \mathrm{tree}$ )(but those produced the highest yields in the previous years). In the ecological growing system, strong crown thinning produced the highest accumulated yield (44 $\mathrm{kg} / \mathrm{tree}$ ). In previous years, they produced the second lowest yields, and turned to the opposite end of the scale. The lowest actual yields $(32,5 \mathrm{~kg})$ are due to strong thinning plus shortening of shoots. It means that the trees could not counterbalance the weak productivity of the past.

\section{Consequences and suggestions}

Our experiment aimed to examine the interaction of pruning techniques and growing systems allowed the following conclusions:

- In the ecological growing system, the reduced security of fruit set is due to the relatively weaker physiological condition of plants.
- In the integrated growing system, the rate of fruit set is higher by about $30 \%$ related to the ecological system.

- In the ecological growing system, a strong thinning of the crown (excision of one-year-old shoots) coupled with shortening of the shoots diminishes the rate of fruit set causing lower yields.

- In the ecological growing system, a strong thinning of the crown coupled with shortening of shoots stimulates shoot growth, which in turn increases the danger of June drop of the fruits set.

- In the integrated growing system, the stimulation of shoot growth caused by pruning the shoots does not impair the final fruit load.

- Regardless of pruning techniques, shoot growth is weaker by $15 \%$ in the ecological growing system than in the integrated one.

- In the ecological growing system, the number of fruiting structure is higher by $15 \%$ as a mean than in the integrated one, which is a consequence of a relatively moderate growing vigour.

- Data accumulated along the biennium on yield are proving that the successive years compensate for yields of the previous year, but a strong thinning coupled with shortening of shoots could not allow the compensation of the low yield.

\section{Practical suggestions}

- In the ecological growing system, thinning of the crown shoots should not be associated with shortening of the rest of shoots.

- In the ecological growing system, the strong thinning of the crown is recommended instead of a moderate thinning.

- In the ecological growing system, let alone the methods of pruning, more fruiting structures are developed in the year of pruning, which may stimulate the appearance of alternate bearing. Therefore, stronger and more often thinning is recommended.

- In the ecological growing system, moderate thinning of the crown should be coupled paralleling with the shortening of shoots being beneficial to the bloom of the next season.

Results called our attention on the fact that in the ecological growing system, right choice of the method of pruning is a decisive factor of a favourable balance of permanent yields.

\section{Acknowledgement}

This work was sponsored by NFÜ TECH 08-A3/2-20080373 grant 


\section{Felhasznált irodalom:}

Gonda, I. (2005): Az ökológiai növényvédelem közvetett elemei. [In. Holb I.: A gyümölcsösök és a szőlő ökológiai növényvédelme.] Mezőgazda Kiadó, Budapest. 34-46.

Holb, I.J., Heijne, B. \& Jeger, M.J. (2005a): The widespread occurrence of overwintered conidial inoculum of Venturia inaequalis on shoots and buds in organic and integrated apple orchards across the Netherlands. Eur J Plant Pathol. 111 (2): 157-168.
Holb, I.J., Heijne, B., Withagen, J.C.M., Gáll, J.M. \& Jeger, M.J. (2005b): Analysis of summer epidemic progress of apple scab in different apple production systems in the Netherlands and Hungary. Phytopathology 95: 1001-1020.

Zahn, F. G. (1986): Intensivierung von Steinobstanlagen durch stärkenbezogene Schnittbehandlung. Erwerbs-Obstbau, 36 (8): 213-220.

Zatykó, I. (1979): Az almafák kondícióját és termőképességét befolyásoló tényezők összehangolása. Újabb kutatási eredmények a gyümölcstermesztésben. 2: 7-19. 